\title{
Studi Fenomenologi Pengendalian Diri Siswa Kelas VIII SMP Negeri 21 Malang
}

\author{
Rita Raditia*, M. Ramli, Irene Maya Simon \\ Universitas Negeri Malang, Jl. Semarang No. 5 Malang, Jawa Timur, Indonesia \\ *Penulis korespondensi, Surel: ritaraditia03@gmail.com
}

Paper received: 2-1-2021; revised: 23-1-2021; accepted: 30-1-2021

\begin{abstract}
The focus of this research is how students understand about self-control, the factors of student selfcontrol, description of student self-control in various aspects, and the efforts of counselor which is conducted to increase student self-control. The approach used in this research is a qualitative approach with an empirical phenomenology design that involves the experience of the subject. The results obtained by researchers are in the form of descriptions of the research focus. Students view self-control as an attempt to refrain from bad things which is harmful for themselves or others. There are two factors that affect student self-control, that are the factors that come from yourself (internal) and the factors that come from outside (external). Some students have been able to control themselves quite well in various aspects, but some have not been able to control themselves well. These three aspects of self-control are reflected in the thinking patterns of students, how to make decisions, and their behavior in everyday life at school. Various efforts have been made by counselors in an effort to help students improve their self-control. These efforts are in the form of preventive efforts through information and guidance services as well as curative efforts in the form of counseling and referral services for students who have not been able to control themselves properly.
\end{abstract}

Keywords: self control; VIII grade students; norms

\begin{abstract}
Abstrak
Fokus penelitian ini adalah bagaimana pemahaman siswa tentang pengendalian diri, faktor-faktor pengendalian diri siswa, gambaran pengendalian diri siswa dalam berbagai aspek, dan usaha-usaha yang dilakukan konselor untuk meningkatkan pengendalian diri siswa. Pendekatan yang digunakan dalam penelitian ini adalah pendekatan kualitatif dengan desain fenomenologi empiris yang melibatkan pengalaman subjek. Hasil yang didapatkan peneliti berupa gambaran dari fokus penelitian. Siswa memandang pengendalian diri sebagai usaha untuk menahan diri dari hal yang buruk agar tidak merugikan diri atau orang lain. Ada dua faktor yang mempengaruhi pengendalian diri siswa yaitu faktor yang berasal dari dalam diri (internal) dan faktor yang berasal dari luar diri (eksternal). Sebagian siswa telah mampu mengendalikan dirinya dengan cukup baik dalam berbagai aspek, namun sebagiannya lagi belum mampu mengendalikan diri dengan baik. Ketiga aspek pengendalian diri tersebut tercermin dari pola berpikir siswa, cara mengambil keputusan, dan perilakunya dalam kehidupan sehari-hari di sekolah. Bermacam usaha telah dilakukan oleh konselor dalam upaya membantu siswa meningkatkan pengendalian dirinya. Usaha tersebut berupa usaha preventif melalui layanan informasi dan bimbingan serta usaha kuratif berupa konseling dan layanan referal bagi siswa yang belum mampu mengendalikan diri dengan baik.
\end{abstract}

Kata kunci: pengendalian diri; siswa kelas VIII; norma

\section{Pendahuluan}

Fenomena penyimpangan moral yang bermula dari pelanggaran tata tertib sekolah masih marak ditemukan di kalangan pelajar Indonesia. Seringkali gengsi, rasa kesetiakawanan yang tinggi dan luapan emosi yang belum stabil sulit dikontrol oleh siswa sehingga timbul dorongan-dorongan untuk melakukan hal hal menyimpang sebagai bentuk dari solidaritas. Saat peneliti melakukan observasi awal di SMP Negeri 21 Malang, ditemukan data bahwa angka 
pelanggaran tata tertib di sekolah tersebut cukup tinggi. Hal ini didukung oleh bukti saat peneliti melakukan Kajian Praktik Lapangan (KPL) sebagai praktikan bimbingan dan konseling. Kasus yang sering ditemukan adalah memakai atribut yang tidak sesuai aturan sekolah, bolos, perkelahian, merokok, dan perundungan.

Setelah menemukan fenomena tersebut peneliti melakukan pengambilan data awal kepada guru bimbingan dan konseling, guru, dan beberapa siswa. Data awal menunjukkan bahwa angka pelanggaran tata tertib yang dilakukan siswa didominasi oleh kelas VIII. Menurut keterangan konselor SMP 21, siswa yang sering melakukan pelanggaran tata tertib sekolah masih belum dapat mengendalikan dirinya secara baik sehingga mudah terpengaruh oleh orang lain.

Indraprasti \& Rachmawati (dalam Pratiwi, 2015) menyatakan bahwa remaja tidak sadar dan belum bisa memperhitungkan akibat jangka pendek atau jangka panjang dari perilakunya, untuk mengatasi keadaan tersebut remaja membutuhkan suatu mekanisme yang dapat membantu mereka dalam mengatur dan mengarahkan perilakunya yaitu kontrol diri. Kondisi emosional remaja belum stabil, gampang berubah-ubah, dan masih sangat mudah dipengaruhi banyak hal. Kondisi tersebut menyebabkan remaja masih perlu mengembangkan kemampuan dalam mengendalikan diri atas arahan dari orang dewasa. Pengendalian diri menurut Nurihsan (2007) adalah tindakan menahan diri untuk tidak melakukan perbuatan-perbuatan yang merugikan dirinya di masa kini maupun di masa yang akan datang. Pengendalian diri yang baik akan memudahkan remaja mencapai kesuksesan dengan cara yang positif.

Menurut William Kay (dalam Yusuf, 2014) salah satu tugas perkembangan remaja adalah Memperkuat self control (kemampuan mengendalikan diri) atas dasar skala nilai, prinsip-prinsip atau falsafah hidup (Weltanschauung). Ada 3 aspek dalam pengendalian diri yaitu pengendalian pikiran, pengendalian pengambilan keputusan, dan pengendalian tingkah laku. Setiap siswa memiliki tingkat pengendalian diri yang berbeda-beda dalam kehidupan sehari-hari di lingkungan sekolah, oleh karena itu peneliti tertarik untuk mengetahui lebih dalam pengendalian diri yang yang dimiliki oleh siswa kelas VIII SMP Negeri 21 Malang. Fokus penelitian ini adalah bagaimana pemahaman siswa tentang pengendalian diri, faktor-faktor pengendalian diri siswa, gambaran pengendalian diri siswa dalam berbagai aspek, dan usahausaha yang dilakukan konselor untuk meningkatkan pengendalian diri siswa.

\section{Metode}

Rancangan penelitian yang digunakan adalah pendekatan kualitatif. Menurut Sugiyono (2015) penelitian kualitatif sering disebut metode penelitian naturalistik karena penelitiannya dilakukan pada kondisi yang alamiah (natural setting). Desain yang digunakan dalam penelitian ini adalah fenomenologi empiris. Penggunaan fenomenologi empiris sebagai studi untuk memahami pengalaman siswa yang nyata, empiris, dan konkret terutama mengenai pengendalian diri. Subjek dalam penelitian ini adalah siswa kelas VIII SMP Negeri 21 Malang yang memiliki prestasi akademis/non akademis dan siswa yang tidak memiliki prestasi di kedua bidang tersebut. Pemilihan subjek menggunakan teknik purposive sampling dengan teknik wawancara dan observasi untuk mendapatkan data pengendalian diri siswa berdasarkan fokus penelitian. Data yang diperoleh kemudian dianalisis melalui tiga tahap yaitu: reduksi data, pengelompokan data, dan penarikan kesimpulan/verifikasi. 


\section{Hasil dan Pembahasan}

\subsection{Hasil}

Data yang akan dipaparkan dalam temuan penelitian merupakan data yang didapatkan peneliti selama melaksanakan penelitian di lapangan. Data-data didapatkan melalui proses wawancara dan observasi berdasarkan fokus penelitian. Peneliti telah mengamati keseharian siswa SMP Negeri 21 Malang selama beberapa waktu sehingga memutuskan untuk mengambil keterangan dari beberapa siswa.

\subsubsection{Pandangan Siswa Tentang Pengendalian Diri}

Pandangan tentang pengendalian diri dapat mengukur sejauh mana pemahaman siswa tentang makna pengendalian diri yang kemudian dapat menjadi acuan siswa dalam berperilaku dalam kehidupan sehari-hari. Siswa memberikan pandangan tentang pengendalian diri yang diartikan sebagai usaha untuk menghindari hal-hal buruk, mengontrol hawa nafsu dan segala emosi yang muncul, serta menahan diri dari hal yang kurang bermanfaat dengan mempertimbangkan segala sesuatu yang akan dilakukan agar tidak merugikan diri atau orang lain. Proses mengendalikan diri atau menahan diri dari hal-hal buruk dan merupakan keterampilan yang penting untuk dikuasai. Apabila siswa memiliki pengendalian diri yang baik, maka ia akan memikirkan segala konsekuensi dari tindakannya sehingga tidak akan sembarangan dalam bertindak.

\subsubsection{Faktor-faktor Pengendalian Diri Siswa}

Kemampuan pengendalian diri tidak begitu saja terbentuk pada individu melainkan dipengaruhi banyak hal. Peran tri pusat pendidikan yaitu keluarga, sekolah, dan masyarakat sangat penting dalam membentuk karakter individu yang kemudian akan mempengaruhi kemampuan individu tersebut dalam mengendalikan dirinya. Sesuai dengan wawancara yang telah dilakukan dengan seluruh informan, dapat diperoleh informasi bahwa ada beberapa faktor yang dapat mempengaruhi pengendalian diri siswa. Faktor tersebut dapat dikategorikan ke dalam faktor internal atau yang berasal dari dalam diri sendiri seperti kemampuan dalam menahan emosi negatif dan ketaatan diri dalam melaksanakan ibadah sesuai agama yang dianut serta faktor eksternal atau yang berasal dari luar antara lain: didikan dan contoh yang diberikan orang tua, pengaruh orang sekitar/teman sepermainan, dan kebiasaan yang ada di lingkungan. Setiap individu memiliki kemampuan yang berbeda-beda dalam menahan diri dari emosi negatif dan ketaatan beribadah. Kedua hal tersebut berpengaruh pada keadaan mental individu dalam menjalani kesehariannya. Selain itu, remaja yang ingin mendapat pengakuan sangat mudah terbujuk oleh ajakan teman dekat agar tetap dapat diterima di lingkup pertemanannya. Lingkungan tempat siswa tumbuh adalah salah satu yang menentukan karakternya. Kebiasaan-kebiasaan yang dilakukan oleh orang-orang sekitar adalah cerminan bagi siswa dalam bertindak dalam kehidupan sehari-hari. 


\subsubsection{Pengendalian Diri Siswa}

\subsubsection{Pengendalian Pikiran}

Dalam hal mengendalikan pikiran, sebagian besar siswa telah mampu memandang suatu peristiwa dari berbagai sisi yang berbeda sehingga dapat mengendalikan pikirannya dengan cukup baik ketika mendapatkan informasi yang tidak diinginkan, namun ada juga beberapa siswa yang belum mampu berpikir secara matang sehingga yang muncul adalah sikap menduga-duga suatu hal tanpa ada keinginan untuk mengkaji lebih jauh atau membiarkannya begitu saja. Ketika mendapat nilai yang tidak sesuai dengan harapan, para siswa berpikir bahwa hal tersebut tidak perlu dipaksakan karena sebagian siswa jarang mengalaminya. Apabila itu terjadi mereka memaklumi, sebagian siswa berusaha memperbaikinya namun sebagian lagi memilih untuk mengabaikannya. Saat dikecewakan oleh seseorang, sebagian siswa berpikir untuk pasrah dan tidak menyesali yang telah terjadi kepadanya. Bagi sebagian siswa lainnya dikecewakan adalah hal yang cukup menyakitkan dan berusaha menjauh namun tetap membantu jika diperlukan. Ketika siswa diberi kritik oleh orang lain, mereka berpikir itu adalah hal yang wajar dan mereka dapat menerima kritik tersebut. Beberapa siswa memilih untuk tidak menghiraukan kritik yang diberikan kepadanya, namun ada juga yang berpikir bahwa kritik adalah hal yang membuatnya lebih dewasa sehingga mau berusaha menjadi pribadi yang lebih baik.

\subsubsection{Pengendalian Pengambilan Keputusan}

Pengendalian diri siswa dalam pengambilan keputusan juga berbeda-beda. Ada beberapa siswa yang masih ragu-ragu dalam mengambil suatu keputusan karena pengaruh orang-orang di sekitarnya sehingga belum dapat mengambil keputusannya secara mandiri, namun ada juga yang tidak mudah terpengaruh orang lain dan dapat mengambil keputusannya sendiri dengan berbagai pertimbangan. Dalam mengambil keputusan sebagian besar siswa memiliki kebebasan dalam mengambil keputusannya sendiri, namun ada beberapa siswa yang masih mengikuti keinginan orang tuanya. Saat hendak mengambil keputusan, hal-hal yang menjadi pertimbangan siswa antara lain : keuntungan dan kerugian yang didapatkan, dampak keputusan yang diambil bagi diri sendiri dan orang lain, serta pendapat orang tua dan teman. Bagi beberapa siswa, pendapat orang lain memiliki pengaruh yang cukup kuat dalam pengambilan suatu keputusan terutama orang tua dan teman. Tidak jarang siswa sulit menolak keinginan orang tua dan teman-temannya. Siswa lainnya memilih untuk mempertimbangkan sendiri dan sulit dipengaruhi keputusannya oleh orang lain. Ketika dapat mengambil keputusan sendiri, para siswa merasa puas, senang, dan lega karena dapat mengikuti keinginan serta kata hatinya sendiri.

\subsubsection{Pengendalian Tindakan/perilaku}

Tindakan yang dilakukan oleh siswa mencerminkan pengendalian diri siswa dalam berperilaku. Sebagian siswa belum mampu mengendalikan perilakunya dengan baik dan mudah terpengaruh oleh perkataan dan tindakan orang lain sehingga cenderung melakukan hal-hal yang melanggar nilai dan norma. Mereka bersikap biasa saja dan bagi 
mereka tidak perlu mematuhi nilai dan norma yang berlaku. Sebagian lainnya sudah cukup mampu mengendalikan diri dengan baik sehingga tidak mudah terpengaruh oleh ajakan temannya untuk melakukan hal-hal yang melanggar nilai dan norma terkecuali dalam keadaan mendesak atau perlu melanggarnya. Saat sedang marah, siswa memiliki bermacam kebiasaan antara lain ada yang menyendiri, melampiaskan kemarahan dengan bermain fisik ke orang yang membuatnya marah, menangis, melampiaskan kemarahan ke benda di sekitarnya, dan diam. Ada beberapa cara yang dilakukan siswa untuk meredam kemarahan, antara lain: bersikap cuek, mencari ketenangan dengan berkumpul bersama teman dan pergi ke suatu tempat, berusaha lebih sabar, menghindari orang yang membuat marah, tidak membahas hal yang membuat marah, memahami sebab kemarahan, dan melampiaskan kemarahan ke benda yang ada di sekitarnya. Ada berbagai macam kebiasaan siswa saat sedang sedih/frustasi dan cara mereka meredamnya, antara lain: menyendiri, menangis, mendengarkan lagu, mencari tempat yang tenang untuk meluapkan kesedihan, curhat, tidur, dan berkumpul bersama teman-teman lalu pergi jalan-jalan ke suatu tempat untuk mencari hiburan.

\subsubsection{Usaha-usaha Konselor}

Ada beberapa usaha yang dilakukan konselor dalam meningkatkan pengendalian diri siswa, antara lain: memberikan nasihat, arahan, dan motivasi bagi siswa, memberikan layanan informasi secara klasikal dan melalui mading sebagai usaha preventif, memberikan layanan konseling untuk seluruh siswa yang membutuhkan, serta layanan kuratif untuk siswa yang memiliki masalah serius. Konselor memberi nasihat, arahan, dan motivasi kepada siswa untuk menjalani hari-hari dengan lebih baik, dan memberi perhatian lebih atau khusus kepada siswa-siswa tertentu yang dianggap kurang mampu mengendalikan dirinya. Salah satu usaha khusus yang dilakukan adalah bekerjasama dengan pondok pesantren untuk menitipkan siswa-siswa yang memiliki poin pelanggaran tata tertib tertinggi selama beberapa minggu untuk dididik mandiri, disiplin, bertanggung jawab, dan agar tidak melalaikan ibadah

\subsection{Pembahasan}

Berdasarkan proses analisis dengan mereduksi data telah dihasilkan temuan penelitian berupa fenomena pengendalian diri siswa kelas VIII SMP Negeri 21 Malang dari seluruh subjek yang telah diwawancarai peneliti sesuai dengan fokus penelitian.

\subsubsection{Pandangan Siswa Tentang Pengendalian Diri}

Hasil penelitian menunjukkan bahwa para siswa memandang pengendalian diri sebagai usaha untuk menghindari hal-hal buruk, mengontrol hawa nafsu dan segala emosi yang muncul, serta menahan diri dari hal yang kurang bermanfaat dengan mempertimbangkan segala sesuatu yang akan dilakukan agar tidak merugikan diri atau orang lain. Sejalan dengan hal tersebut, Hurlock (dalam Suherman, 2016) menjelaskan individu yang memiliki self-control memiliki kesiapan diri untuk berperilaku sesuai dengan tuntutan norma, adat, nilai-nilai yang bersumber dari ajaran agama, dan tuntutan lingkungan masyarakat tempat ia tinggal, emosinya tidak lagi meledak-ledak di hadapan orang lain, melainkan menunggu saat dan tempat yang lebih tepat untuk mengungkapkan emosinya dengan cara-cara yang lebih 
diterima. Pendapat tersebut mengisyaratkan bahwa pengendalian diri yang baik akan membawa siswa pada perilaku positif yang dapat diterima oleh masyarakat luas. Siswa yang memiliki kemampuan pengendalian diri akan mematuhi peraturan yang berlaku di sekolah, melaksanakan ibadah dengan baik, memiliki sikap sopan santun terhadap guru dan temanteman, mampu berprestasi, dan tidak menunjukkan emosi yang meledak-ledak saat sedang marah. Sebaliknya, siswa dengan kemampuan pengendalian diri rendah cenderung kurang memperhitungkan konsekuensi dari segala tindakan yang dilakukan sehingga akan mengarah pada perilaku yang menyimpang dari nilai dan norma yang berlaku di lingkungan.

\subsubsection{Faktor-faktor Pengendalian Diri Siswa}

Banyak hal yang mempengaruhi kemampuan seseorang dalam mengendalikan dirinya. Berdasarkan penelitian yang telah dilakukan dapat diketahui bahwa faktor-faktor yang mempengaruhi kemampuan pengendalian diri siswa dikategorikan ke dalam faktor internal (dalam diri) dan faktor eksternal (luar diri). Faktor internal atau yang berasal dari dalam diri sendiri seperti kemampuan dalam menahan dorongan emosi negatif dan ketaatan diri dalam melaksanakan ibadah sesuai agama yang dianut. Hurlock (dalam Yanti,2016) yang menyatakan bahwa perkembangan kontrol diri pada remaja juga sehubungan dengan kematangan emosi. Kematangan emosi pada remaja dapat dilihat dari kemampuannya untuk tidak meluapkan emosi pada saat yang tidak tepat di hadapan orang lain. Pada penelitian Ragwan Mohsen Alaydrus, yang berjudul Membangun Kontrol Diri Remaja Melalui Pendekatan Islam Neuroscience (dalam Ali, Rohmah, \& Andrajati, 2020), dapat disimpulkan bahwa proses menuju dewasa oleh seorang remaja harus dibentengi dengan fondasi spiritual dan psikologis supaya individu memperoleh kemampuan pengendalian diri. Agama memiliki nilai-nilai yang dapat dijadikan pedoman pembelajaran sehingga bisa menjadi fondasi spiritual bagi siswa yang nantinya dapat membina pengendalian diri.

Faktor eksternal atau yang berasal dari luar diri individu diantaranya adalah didikan dan contoh yang diberikan orang tua, kebiasaan yang ada di lingkungan, serta pengaruh orang sekitar/teman sepermainan. Orang tua yang konsisten dalam menerapkan disiplin sejak dini dan memberikan konsekuensi apabila anak melakukan hal menyimpang dari aturan yang telah ditetapkan akan diinternalisasikan oleh anak dan menjadi kontrol diri baginya. Sebaliknya, menurut Aroma dan Suminar (2012) seorang remaja yang berasal dari keluarga yang minim dukungan terhadap anak, minim pengawasan, serta orang tua yang menerapkan pola disiplin secara tidak efektif akan tumbuh menjadi individu yang memiliki kontrol diri rendah. Selain orang tua, masyarakat juga memiliki peran dalam membentuk kemampuan pengendalian diri remaja. Kemampuan mengendalikan diri merupakan hasil belajar, yang berhubungan dengan proses pendidikan, sementara pendidikan selalu dilatarbelakangi oleh kultur dimana pendidikan tersebut berlangsung. (Sriyanti, 2012). Nilai dan norma sosial yang berlaku di masyarakat adalah alat kontrol diri bagi remaja dalam kehidupan sosialnya. Sejalan dengan hal tersebut, peran masyarakat dalam melakukan pengawasan terhadap perilaku remaja dan ketegasan dalam menegakkan nilai dan norma yang berlaku juga menjadi faktor penentu tinggi atau rendahnya pengendalian diri remaja.

Faktor eksternal lainnya yang menentukan pengendalian diri remaja adalah teman sepermainan. Harris (dalam Titisari, 2017) berpendapat bahwa kelompok sebaya menjadi konteks yang lebih penting bagi kaum muda daripada bagi para orang tua, terutama dalam hal pengaruh mereka pada pengambilan keputusan dalam jangka pendek. Remaja yang sedang 
mencari jati dirinya terus melakukan interaksi sosial dengan remaja lainnya. Remaja sangat suka mencoba hal-hal baru untuk mendapatkan pengakuan. Hal ini sangat rentan apabila salah memilih teman dalam bergaul karena remaja cenderung mengikuti kebiasaan teman sepermainannya.

\subsubsection{Pengendalian Diri Siswa}

Menurut Logue \& Forzano (dalam Aroma dan Suminar, 2012) ciri-ciri remaja yang memiliki pengendalian diri yang tinggi antara lain : 1) tekun dan tetap bertahan dengan tugas yang harus dikerjakan, walaupun menghadapi banyak hambatan; 2) dapat mengubah perilaku menyesuaikan dengan aturan dan norma yang berlaku dimana ia berada; 3) tidak menunjukkan perilaku yang emosional atau meledak-ledak; dan 4) bersifat toleran atau dapat menyesuaikan diri terhadap situasi yang tidak dikehendaki. Siswa yang memiliki pengendalian diri tinggi adalah siswa yang tidak mudah patah semangat saat menghadapi kegagalan, dapat beradaptasi dengan peraturan yang berlaku di sekolah dengan baik, mampu menjaga emosinya dengan stabil, dan bisa menghadapi situasi yang tidak diinginkan dengan cara yang positif.

\subsubsection{Pengendalian Pikiran}

Dalam hal mengendalikan pikiran, sebagian siswa telah mampu memandang suatu peristiwa dari berbagai sisi yang berbeda sehingga dapat mengendalikan pikirannya dengan cukup baik ketika mendapatkan informasi yang tidak diinginkan. Implementasi pengendalian diri siswa dalam hal ini seperti saat gagal dalam mendapatkan nilai bagus, mendapatkan kritik dari orang lain, dan dikecewakan oleh orang lain. Mereka memandang hal tersebut adalah sesuatu yang wajar, ada penyebabnya, dan perlu diperbaiki agar selanjutnya dapat lebih baik dari sebelumnya. Seseorang yang mampu menginterpretasi, menilai, atau menghubungkan suatu peristiwa di sekitarnya ke dalam suatu kerangka pikir yang positif, maka ia akan mampu mengendalikan dirinya (Ariningsun, 2014). Bagi siswa yang memiliki kemampuan mengendalikan pikiran, semua hal yang terjadi ada sebab dan akibatnya. Apabila hal tersebut tidak dipikirkan dengan matang dan berusaha dicari solusinya, maka akan semakin bertumpuk dan berpengaruh kurang baik untuk mereka. Sebagian kecil siswa lainnya belum mampu berpikir secara matang sehingga yang muncul adalah sikap menduga-duga suatu hal tanpa ada keinginan untuk mengkaji lebih jauh atau membiarkannya begitu saja. Apabila menghadapi masalah, siswa yang ada di dalam golongan ini cenderung mengandalkan kemampuan fisik untuk menyelesaikannya. Sebagian dari mereka tidak ingin larut dalam masalah yang dihadapi dan memilih menghindar untuk memperoleh ketenangan.

\subsubsection{Pengendalian Pengambilan Keputusan}

Sebagian siswa sudah dapat mengambil keputusannya sendiri dengan berbagai pertimbangan, dan tidak mudah terpengaruh orang lain. Mereka akan berpegang teguh atas keyakinan yang dimiliki dengan segala pertimbangan yang ada bukan hanya karena ingin mencapai suatu kepuasan. Siswa-siswa ini juga tidak sembarangan dalam mengambil keputusan melainkan atas dasar nilai dan norma yang berlaku di lingkungan serta ajaran agama yang dianut. Casey (dalam Gunawan, 2017) mengatakan, kemampuan mengontrol 
diri terus berkembang secara bertahap dari anak-anak hingga remaja. Kemampuan ini tidak akan sepenuhnya matang hingga akhir remaja. Meskipun sudah memiliki kemampuan dalam mengontrol diri, siswa harus tetap berhati-hati dan benar-benar berpikir secara matang saat hendak mengambil sebuah keputusan karena sejatinya kemampuan yang dimiliki belum sepenuhnya matang. Pengawasan dan arahan dari orang dewasa di sekitarnya masih dibutuhkan. Sebagian siswa lainnya masih ragu-ragu dalam mengambil suatu keputusan karena pengaruh orang-orang di sekitarnya, sehingga belum dapat mengambil keputusan secara mandiri. Mereka sangat mudah dipengaruhi dan kurang percaya diri dengan keputusan yang diambil. Segala hal diputuskan atas dasar motif-motif tertentu bukan dari akibat yang akan ditimbulkan atas keputusan tersebut, melainkan hanya pencapaian atau kepuasan yang diperoleh apabila telah memutuskan sesuatu. Menurut Averill (dalam Waluwandja \& Dami, 2018) pengendalian diri dalam mengambil sebuah keputusan akan berfungsi dengan baik jika ada kesempatan, kebebasan, dan kemungkinan untuk individu memilih berbagai alternatif tindakan. Siswa yang dibatasi kesempatan dan kebebasannya dalam mengambil keputusan sesuai hal yang diyakini akan terhambat dalam kemampuan pengendalian keputusan. Mereka juga akan kesulitan dalam menentukan berbagai alternatif tindakan dalam kesehariannya di lingkungan sosial.

\subsubsection{Pengendalian Tindakan/perilaku}

Tindakan yang dilakukan oleh siswa mencerminkan pengendalian diri siswa dalam berperilaku. Menurut Gino, Schweitzer, Mead, \& Ariely (dalam Komsi, Hambali, \& Ramli, 2018) bila pengendalian diri seorang individu lemah, mereka cenderung bertingkah laku negatif atau menunjukan gejala perilaku menyimpang. Siswa dengan pengendalian diri rendah akan menunjukkan tingkah laku negatif dalam kesehariannya, sedangkan siswa yang memiliki pengendalian diri tinggi akan menunjukkan tingkah laku positif. Berdasarkan penelitian yang telah dilakukan, ditemukan bahwa sebagian siswa belum mampu mengendalikan perilakunya dengan baik dan mudah terpengaruh oleh perkataan serta tindakan orang lain sehingga cenderung melakukan hal-hal yang melanggar nilai dan norma. Bagi siswa-siswa tersebut, nilai dan norma yang berlaku bukan suatu patokan dalam melakukan suatu tindakan sehingga mereka cenderung melanggarnya. Alasan harga diri, pengakuan, dan solidaritas sering dijadikan alat ukur dalam melakukan suatu hal meski bertentangan dengan nilai dan norma yang ada. Sebagian siswa lainnya sudah mampu mengendalikan diri dengan baik sehingga dan tidak mudah terpengaruh oleh ajakan orang lain untuk melakukan hal-hal yang melanggar nilai dan norma. Sari (2017) mengemukakan, semakin tinggi kontrol diri seseorang maka semakin rendah agresivitasnya. Sebaliknya semakin rendah kontrol diri maka semakin tinggi agresivitasnya. Siswa yang ada di dalam golongan ini biasanya memiliki citra baik di hadapan guru dan teman-temannya karena keseharian mereka di sekolah. Mereka tidak luput dari kesalahan-kesalahan kecil namun berusaha menghindari kesalahan yang besar terutama melanggar nilai dan norma yang berlaku. Dalam kesehariannya, siswa yang memiliki kemampuan dalam pengendalian perilaku akan menunjukkan perilaku yang positif dan menginspirasi bagi orang-orang di sekitarnya. 


\subsubsection{Usaha-usaha Konselor}

Bimbingan dan konseling merupakan salah satu komponen yang sangat penting dalam pendidikan di Sekolah. Menurut Prayitno (dalam Waluwandja \& Dami,2018) komponen ini berperan dalam memberikan bimbingan, arahan atau bantuan kepada peserta didik untuk mengenal dan menerima lingkungan secara positif dan dinamis serta mampu mengambil keputusan, mengendalikan diri secara baik, mengarahkan dan mewujudkan dirinya secara efektif dan dinamis dan produktif sesuai dengan peranan yang diinginkan di masa depan. Pernyataan tersebut menyebutkan bahwa konselor memiliki peran aktif dalam merencanakan kegiatan penyelesaian studi, perkembangan siswa, dan membantu siswa untuk mengembangkan seluruh potensi dan kekuatan yang dimilikinya seoptimal mungkin agar siswa mampu mengendalikan dirinya sewaktu mereka ditempatkan dimana saja.

Berdasarkan hasil penelitian dapat diketahui bahwa konselor telah melakukan beberapa hal untuk membantu siswa mengembangkan kemampuan pengendalian dirinya. Usaha pertama yang dilakukan oleh konselor adalah usaha preventif berupa pemberian nasehat, arahan, dan motivasi bagi siswa untuk membangkitkan semangat siswa dan agar siswa dapat menjalani hari-hari dengan lebih baik. Kemudian, konselor juga memberikan layanan informasi secara klasikal dan melalui mading tentang banyak hal termasuk pengendalian diri. Usaha preventif lainnya yang dilakukan konselor yaitu menyempatkan diri untuk menyapa dan bercengkrama dengan siswa ketika ada waktu luang untuk membangun hubungan yang baik. Konselor berusaha masuk ke dalam dunia siswa dan memahami kebutuhan-kebutuhannya tanpa mengabaikan tugas yang lainnya.

Usaha kedua yang dilakukan oleh konselor adalah memberikan layanan kuratif berupa konseling dan layanan referal untuk siswa yang memiliki masalah serius dan butuh penanganan lebih lanjut, serta memberi perhatian khusus kepada siswa-siswa tertentu yang dianggap kurang mampu mengendalikan dirinya. Salah satu usaha khusus yang dilakukan adalah bekerjasama dengan pondok pesantren atas persetujuan pihak sekolah untuk menitipkan siswa-siswa yang memiliki poin pelanggaran tata tertib tertinggi selama beberapa minggu untuk dididik mandiri, disiplin, bertanggung jawab, dan agar tidak melalaikan ibadah. Hal ini dilakukan agar siswa yang kurang mampu menyesuaikan diri dengan tata tertib yang berlaku di sekolah dapat berperilaku lebih baik setelah kembali dari pondok pesantren.

\section{Simpulan}

Berdasarkan analisis yang telah dilakukan dapat diperoleh empat simpulan berdasarkan fokus penelitian. Pertama, siswa memandang pengendalian diri sebagai usaha untuk menghindari hal-hal buruk, mengontrol hawa nafsu dan segala emosi yang muncul, serta menahan diri dari hal yang kurang bermanfaat dengan mempertimbangkan segala sesuatu yang akan dilakukan agar tidak merugikan diri atau orang lain. Kedua, faktor-faktor yang mempengaruhi kemampuan pengendalian diri siswa antara lain : kemampuan dalam menahan dorongan emosi negatif, ketaatan diri dalam melaksanakan ibadah sesuai agama yang dianut, didikan dan contoh yang diberikan orang tua, kebiasaan yang ada di lingkungan, serta pengaruh orang sekitar/teman sepermainan. Ketiga, dalam hal mengendalikan pikiran, sebagian siswa telah mampu memandang suatu peristiwa dari sisi positif sehingga dapat mengendalikan pikirannya dengan cukup baik. Sebagian kecil siswa lainnya belum mampu berpikir secara matang dan cenderung menghindar dari masalah untuk memperoleh ketenangan. Dalam mengambil keputusan, sebagian siswa 
belum diberikan kebebasan dan masih tergantung pada pertimbangan orang lain disekitarnya sehingga ragu-ragu untuk menentukan pilihannya sendiri. Sebagian siswa lainnya tidak mudah terpengaruh oleh pendapat orang lain sehingga dapat mengambil keputusannya sendiri dengan berbagai pertimbangan yang matang disertai rasa tanggung jawab. Dalam mengendalikan perilaku, sebagian siswa belum mampu mengendalikan perilakunya dengan baik karena mudah terpengaruh oleh ajakan dan tindakan orang lain sehingga cenderung melakukan hal-hal yang melanggar nilai dan norma. Sebagian lainnya sudah cukup mampu mengendalikan diri dengan baik sehingga dapat mengarahkan perilakunya ke arah yang positif dan tidak mudah terpengaruh oleh ajakan temannya untuk melakukan hal-hal yang melanggar nilai dan norma. Keempat, usaha-usaha yang telah dilakukan konselor untuk membantu siswa meningkatkan pengendalian diri antara lain : memberikan nasihat, arahan, dan motivasi, memberikan layanan informasi secara klasikal dan melalui mading, memberikan layanan konseling untuk seluruh siswa yang membutuhkan, menyempatkan diri untuk menyapa dan bercengkrama dengan siswa ketika ada waktu luang, memberikan layanan referal untuk siswa yang memiliki masalah serius dan butuh penanganan lebih lanjut, serta memberi perhatian khusus kepada siswasiswa tertentu yang dianggap kurang mampu mengendalikan dirinya.

\section{Daftar Rujukan}

Ali, M., Rohmah, S., \& Andrajati, N. H. (2020). Integrasi Nilai Agama pada Pembelajaran IPS dalam Membina Self Control Siswa. Dirasah: Jurnal Studi Ilmu dan Manajemen Pendidikan Islam, 3(2), 90-97.

Ariningsun, A. (2014). Penerapan Konseling Kelompok Rasional Emotif Perilaku untuk Meningkatkan Pengendalian Diri Siswa Kelas VIII SMP Negeri 4 Panggul Trenggalek. Jurnal BK UNESA, 4(3).

Aroma, I. S., \& Suminar, D. R. (2012). Hubungan antara tingkat kontrol diri dengan kecenderungan perilaku kenakalan remaja. Jurnal Psikologi Pendidikan dan Perkembangan, 1(2), 1-6.

Gunawan, L. N. (2017). Hubungan antara kontrol diri dan penyesuaian diri dengan kedisiplinan siswa MTs Sulaiman Yasin Samarinda. Jurnal Psikoborneo, 5(1), 104-117.

Komsi, D. N., Hambali, I. M., \& Ramli, M. (2018). Kontribusi pola asuh orang tua demokratis, kontrol diri, konsep diri terhadap motivasi belajar siswa. Psychology, Evaluation, and Technology in Educational Research, 1(1), 55-61.

Nurihsan, A. J. (2005). Strategi layanan bimbingan dan konseling. Bandung: Refika Aditama.

Pratiwi, M. D. (2015). Keefektifan penggunaan paket bimbingan pengendalian emosi untuk meningkatkan kontrol diri siswa kelas VIII SMP Negeri 1 Wlingi.

Sari, S. P. (2017). Teknik Psikodrama dalam Mengembangkan Kontrol Diri Siswa. Jurnal Fokus Konseling, 3(2), 123-137

Sriyanti, L. (2012). Pembentukan self control dalam perspektif nilai multikultural. MUDARRISA: Jurnal Kajian Pendidikan Islam, 4(1).

Sugiyono. (2015). Metode Penelitian Kuantitatif, Kualitatif, dan R\&D. Bandung: Alfabeta

Suherman, M. M. (2016). Efektivitas Strategi Permainan dalam Mengembangkan Self-Control Siswa. Jurnal Penelitian Pendidikan, 16(2), 194-201.

Titisari, H. T. D. (2018). Hubungan antara Penyesuaian diri dan Kontrol diri dengan Perilaku Delikuen pada siswa SMA Muhammadiyah 1 Jombang. Psikodimensia, 16(2), 131-141.

Waluwandja, P. A., \& Dami, Z. A. (2018). Upaya Pengendalian Diri Melalui Layanan Bimbingan Kelompok. Ciencias: Jurnal Penelitian Dan Pengembangan Pendidikan, 1(1), 109-123.

Yanti, G. D. (2016). Studi deskriptif kontrol diri terhadap perilaku konsumtif siswa SMK Malang.

Yusuf, S. (2014). Psikologi Perkembangan Anak \& Remaja. Bandung: Remaja Rosdakarya. 